\title{
The Effects of Rodenticide Residues Deposited in Eggs of Tyto alba to Eggshell Thickness
}

(Kesan Residu Racun Tikus dalam Telur Tyto alba kepada Penipisan Kulit Telur)

\author{
HASBER SAlim, HAFIDZI MOHD NOOR*, NOOR HiSHAM HAMID, DZOLKHIFLI OMAR, \\ AZHAR KASIM \& CIK MOHD RIZUAN Z. ABIDIN
}

\begin{abstract}
The deposition of anticoagulant residues in the eggs of barn owls, Tyto alba by assessing eggshell thickness were investigated in oil palm plantations. Three study plots were set aside; one plot each baited with chlorophacinone and bromadiolone, respectively and the third was left unbaited. Four baiting campaigns were conducted on the rodenticide designated plots, coinciding with the breeding seasons of $\mathrm{T}$. alba. High performance liquid chromatography (HPLC) showed that $29.73 \%(\mathrm{n}=37)$ and $5.35 \%(\mathrm{n}=56)$ of addled eggs collected from rodenticide treated plots contained bromadiolone and chlorophacinone, respectively, with mean concentration of residues from 0.009 to $0.031 \mu \mathrm{g} / \mathrm{g}$ wet weight. None of the addled eggs $(\mathrm{n}=28)$ collected from the unbaited plot contained bromadiolone or chlorophacinone residues. The detection of rodenticide residues in both albumen and yolk indicated high risk of secondary poisoning to both compounds. However, low levels of residues detected have no effects on shape of egg, eggshell mass or thickness.
\end{abstract}

Keywords: Anticoagulant rodenticide; barn owl; eggshell thickness; secondary poisoning

ABSTRAK

Suatu kajian lapangan di ladang kelapa sawit telah dijalankan untuk menilai potensi residu racun tikus antikoagulan dipindahkan daripada ibu burung pungguk, Tyto alba kepada telur dan kesan residu tersebut terhadap kualiti dan penipisan kulit telur. Tiga kawasan kajian telah dipilih dengan dua dirawat dengan racun tikus antikoagulan iaitu bromadiolon dan klorofasinon serta satu kawasan lagi tanpa rawatan sebagai kawalan. Empat kempen pengumpanan ataupun rawatan telah dijalankan semasa musim pembiakan T. alba di kawasan rawatan racun tikus antikoagulan. Keputusan analisis kromatografi cecair prestasi tinggi (HPLC) menunjukkan bilangan sampel telur T. alba yang diambil dari kawasan rawatan racun tikus antikoagulan yang mengandungi residu adalah masing-masing sebanyak $29.73 \%$ $(\mathrm{n}=37)$ bagi rawatan bromadiolon dan sebanyak $5.35 \%(\mathrm{n}=56)$ bagi rawatan klorofasinon. Residu yang dikesan adalah dalam julat 0.009 hingga 0.031 g g/g berat basah. Analisis residu juga menunjukkan tiada sampel telur yang diambil dari kawasan tanpa rawatan racun tikus antikoagulan $(\mathrm{n}=28)$ mengandungi residu bromadiolon mahupun klorofasinon. Pengesanan residu bromadiolon dan klorofasinon di dalam sampel telur menunjukkan risiko keracunan sekunder yang tinggi terhadap T. alba di kedua-dua kawasan kajian dan wujudnya potensi racun tikus antikoagulan ini dipindahkan ke dalam telur. Namun, kandungan residu yang rendah di dalam telur tidak memberikan kesan terhadap bentuk telur, berat cengkerang mahupun penipisan cengkerang telur T. alba.

Kata kunci: Burung pungguk; keracunan sekunder; racun ketebalan kulit telur; tikus antikoagulan

\section{INTRODUCTION}

Anticoagulant rodenticide residues in avain eggs from sublethal exposure has been amply investigated (Fisher 2009; Kammerer et al. 1999; Mario \& Grazia 2010). Kammerer et al. (1999) investigated residue depletion in eggs after warfarin ingestion by domestic hens reported the latter was persistent in the albumen for three to four days. In comparison the yolk showed an increased concentration to day six before gradually subsiding and untraceable on day 14. Fisher (2009) administered brodifacoum (0.50 $\mathrm{mg} / \mathrm{kg}$ ) to domesticated jungle fowl (Gallus gallus) and detected high residues in the eggs $(0.06 \mu \mathrm{g} / \mathrm{g})$ after 14 days. Similarly, Mario and Grazia (2010) reported bromadiolone residues in the egg yolk of domestic hens from the third to the ninth day following several doses $(10-60 \mathrm{mg} / \mathrm{kg})$ of inoculation of the former.

The possibility of contamination of eggs by anticoagulant rodenticide in kiwi (Apteryx mantelli) has been suggested by Robertson et al. (1999), however, they attributed the lack of detection of residues to the low sample size tested in the field. Naim et al. (2012) reported more than $60 \%(n=36)$ of abandoned eggs of T. alba collected in oil palm where warfarin and brodifacoum were applied contained traces of both the latters' residues. They also reported brodifacoum exposure lead to a more rounded egg, lower egg shell mass and thinner eggshell. The objective of this study was to investigate the deposition of bromadiolone and chlorophacinone residues in eggs 
of barn owl, T. alba and the physical effects of exposure to both anticoagulants to eggshell thickness were also investigated.

\section{MATERIALS AND METHODS}

\section{STUDY SITE AND TREATMENT}

The study was conducted in a mature oil palm plantation in FELDA Jengka 24, FELDA PPPTR and FELDA Gelanggi 5, Jerantut in the State of Pahang, Malaysia. Two types of anticoagulant rodenticides; first generation, chlorophacinone $(0.005 \%$ a.i) and second generation, bromadiolone $(0.005 \%$ a.i) were applied at FELDA PPPTR and FELDA Gelanggi 5, respectively. FELDA Jengka 24 was kept rodenticide free as the control plot. The sites were sufficiently far apart $(\sim 25 \mathrm{~km})$ to reduce the likely possibility of barn owls hunting across treatment plots. Baiting was conducted twice a year in March and September, which coincided with the peak breeding season of the barn owls in the study areas. The four baiting campaigns were carried out from 7-10 March 2011, 20-24 September 2011, 26-29 March 2012 and 10-13 September 2012 consecutively. Each campaign involved two baiting rounds with a time lapse of 14 days. Baits were placed at the base of the palm trees of every palm in the designated plots.

\section{COLLECTION OF EGGS AND PREPARATION OF THE EGGSHELLS}

Only addled eggs were collected from the nest boxes; brought to the laboratory for assessment of egg shape (length/breadth), eggshell mass and thickness. After egg dimensions were measured with a pair of calliper $\left(\right.$ Mitutoyo ${ }^{\circledR}$ ), after which egg contents emptied for HPLC analysis. Eggs were cleaned under running tap water to remove dirt and traces of faeces. Shell membrane was gently removed by tap water using a soft tooth-brush and allowed to dry to constant mass at $30^{\circ} \mathrm{C}$ overnight (Green 1998). Eggshell was weighed (accurate to $0.0001 \mathrm{~g}$ ) a digital weighing scale $\left(\right.$ Ohaus $^{\circledR}$ ) and thickness (accurate to $0.01 \mathrm{~mm}$ ) measured with a Peacock dial pipe gauge (Ozaki Ltd) around the egg 'waist' or equator $\mathrm{r}$ (Eeva et al. 1997). Shell thickness was determined by taking the average thickness of nine small pieces of eggshells randomly picked near the equator of the egg.

\section{HPLC ANALYSIS}

HPLC analysis was conducted at the Toxicology laboratory, Department of Plant Protection, Faculty of Agriculture, Universiti Putra Malaysia, Malaysia. The HPLC system (Water, USA) consist of a controller (model 600) with an auto-sampler (model 717), an ultra violet (UV) detector (model 2996) and a fluorescence detector (model 2475). A reversed-phase C18 column (5 $\mu$ m particle size, 4.6 $\mathrm{mm}(\mathrm{ID}) \times 250 \mathrm{~mm}(\mathrm{~L})$ ) was used for analysis (Nucleosil $\&$ Nucleodur () . The mobile phase for detection of chlorophacinone was acetonitrile: ortho phosphoric acid, $0.5 \%$ (90:10 for $\mathrm{v} / \mathrm{v})$, while for bromadiolone was Methanol: distilled water: acetic acid glacial (70:25: 5 for $\mathrm{v} / \mathrm{v})$. The mobile phase flow rate was $1.0 \mathrm{~mL} /$ min. The UV detector was monitored from 240 to 340 $\mathrm{nm}$ with quantification done at $285 \mathrm{~nm}$ for detection of chlorophacinone. The fluorescence detector was set at $310 \mathrm{~nm}$ excitation and $390 \mathrm{~nm}$ emissions for detection of bromadiolone. The injection volume was set at $20 \mu \mathrm{L}$.

\section{SAMPLE PREPARATION AND EXTRACTION}

Analysis of egg samples was carried out by modifications of methods described by Mario and Grazia (2010) and Pouliquen et al. (1997). Eggs weight recorded and contents emptied; the yolk and albumin were mixed to homogeneity and weighed. Two g of the egg contents were mixed with anhydrous sodium sulphate and $10 \mathrm{~mL}$ of the extraction solvent, acetonitrile. The mixture was vortexed to homogeniety, sonicated and centrifuged. The supernatant was decanted and extraction was repeated twice. The combined supernatants were evaporated in a rotavapor (Buchi R-215) at $40^{\circ} \mathrm{C}$ to dryness. The dried extract was then reconstituted with $1 \mathrm{~mL}$ of mobile phase and filtered through a Cronus Filter Yellow $13 \mathrm{~mm}, 0.45$ $\mu \mathrm{m}$ before kept in a vial for HPLC analysis.

\section{STANDARD AND CALIBRATION CURVE}

Chlorophacinone and bromadiolone standard (Pestanal $\left.{ }^{\circledR}\right)$ with 98.4 and $97.6 \%$ were respectively obtained from Sigma-Aldrich, Germany. A stock standard solution of chlorophacinone was prepared in acetonitrile; while for bromadiolone in methanol - dicholoromethane (60:40, $\mathrm{v} / \mathrm{v})$. A stock solution of $100 \mathrm{ppm}$ was prepared by dissolving $5 \mathrm{mg}$ analytical standard in $50 \mathrm{~mL}$ of solvents. Working standards, ranging in concentration from 0.01 to $10 \mathrm{ppm}$ were prepared from the stock standard solution. The working standard solutions were then used to prepare standard curve and spiking. In HPLC system, response of both rodenticides was linear for 6 standard solutions at concentrations of $0.05,0.1,0.5,1,5$ and $10 \mathrm{ppm}$. Linearity of calibration was assessed from a linear regression of response (area) versus concentration of rodenticides, resulting in $r^{2}$ value of 0.999 . The average retention time of bromadiolone and chlorophacinone was $4.9 \mathrm{~m}$ and 5.5 min, respectively.

\section{FORTIFICATION AND LIMIT OF DETECTION (LOD)}

The samples were spiked with three fortification concentrations of 1.0, 5.0 and $10.0 \mathrm{ppm}$ of each standard solution. Recovery rates were assessed from spiked control samples of rodenticides with the fortification concentrations. It was evident that both rodenticides showed good recoveries at low and high concentrations ranged from 82 to $85 \%$, respectively. Detection limits for each rodenticide were assessed from calibration standards using statistical regression with three replications. The 
estimated LOD of the bromadiolone and chlorophacinon were $0.005 \mathrm{ppm}$ and $0.002 \mathrm{ppm}$, respectively.

\section{QUALITY CONTROL (QC) SAMPLES}

A blank containing purely acetonitrile and methanol was injected between each sample to monitor for any possible contamination due to carry over. Blank samples of chicken eggs were also prepared and extracted similar to the samples. All blank solvents and blank samples were below the analytical limit of detection (LOD) for both rodenticides tested.

\section{RESULTS AND DISCUSSION}

\section{RODENTICIDE RESIDUE IN EGGS OF Tyto alba}

Table 1 shows the number of eggs detected with residues and their mean concentrations. Out of the 37 eggs collected in the bromadiolone treated plot, $29.73 \%(n=11)$ contained bromadiolone residues ranging from $0.011-0.052 \mu \mathrm{g} / \mathrm{g}$. In the chlorophacinone treated plot, from a total of 56 eggs only $5.35 \%(n=3)$ contained chlorophacinone residue ranging from $0.007-0.015 \mu \mathrm{g} / \mathrm{g}$. No eggs $(n=28)$ in the rodenticide free plot contained bromadiolone or chlorophacinone residues. The concentration levels of residues in eggs were higher in the bromadiolone than the chlorophacinone treated plots in all seasons. Moreover, the number of eggs detected with bromadiolone residue $(n=11)$ were higher than chlorophacinone treated plots $(n=3)$ despite more eggs were collected in the latter $(n=56)$ compared to the former $(n=37)$. Based on the concentration of residues detected, bromadiolone seems more persistent chlorophacinone in barn owl eggs.

The findings are in agreement with Erickson and Urban (2004) study who found that chlorophacinone was less persistent in animal tissues than bromadiolone (). The presence of rodenticide residues in $15.05 \%$ $(14 / 93)$ of addled eggs in rodenticide treated plots could suggest the adverse effects on the early development of eggs in the ovaries. Fisher (2009) detected residues of brodifacoum in both the ovary and eggs of hens at the same high concentration of up to $0.061 \mu \mathrm{g} / \mathrm{g}$. He suggested brodifacoum in ovarian tissue if present will be partly transferred to the developing eggs. Hence the possibility of rodenticides affecting egg viability cannot be ruled out. Nevertheless avian egg viability can be influenced by many factors such as parent fertility, temperature, poor incubation, disease and nutrition (Dzoma et al. 2010; Koelkebeck 2012; Taylor 1970).

Studies by Kammerer et al. (1999) and Mario and Grazia (2010) have indicated that residues are detected in eggs produced by domestic chickens for up to two weeks after the latter are orally administered with single dose of walfarin and bromadiolone. However, whether residues will adversely affect the development of fertilized eggs or the fitness of hatched chicks is unknown. Both studies involved single feeding with a sub-lethal dose of anticoagulant rodenticides. In a baiting situation, $T$. alba may consume several poisoned rats equivalent to repeated intakes of sub-lethal dose of rodenticides. In that circumstances rodenticides may accumulate in the body tissues at higher levels and for a longer time than suggested by both previous studies in which only a single, sub-lethal dose is administered.

\section{EGG SHAPE, EGGSHELL MASS AND EGGSHELL THICKNESS}

Table 2 shows the egg shape quantified as the ratio of length to breadth $(\mathrm{L}: \mathrm{B})$ in bromadiolone, chlorophacinone and rodenticide free area. Eggs collected from rodenticide free area showed similar ratios in all breeding seasons, with a total mean ratio of $1.228 \pm 0.03(n=24)$. The highest ratio of $1.230 \pm 0.02(n=4)$ was recorded in the fourth breeding season and the lowest ratio of $1.224 \pm 0.01 \quad(n=5)$ was recorded in second breeding season. Similarly, eggs collected from the bromadiolone treated plot had a mean ratio of $1.230 \pm 0.03(n=37)$ and tend to stabilize over the

TABLE 1. Residues of rodenticides detected (Mean \pm S.E) in eggs of Tyto alba

\begin{tabular}{cccccc}
\hline \multirow{2}{*}{ Treatment } & Breeding season & $(\mathrm{n})$ & \multicolumn{2}{c}{ Mean residue $(\mu \mathrm{g} / \mathrm{g}$ wet weight) } & Detected with residues \\
& 1 & 7 & ND & ND & \\
& 2 & 11 & $0.031 \pm 0.02(2)$ & ND & $29.73 \%$ \\
Broma & 3 & 8 & $0.015 \pm 0.01(5)$ & ND & \\
& 4 & 11 & $0.018 \pm 0.00(4)$ & ND & \\
& 1 & 4 & ND & ND & $5.35 \%$ \\
Chloro & 2 & 15 & ND & $0.009 \pm 0.00(1)$ & \\
& 3 & 19 & ND & ND & \\
& 4 & 18 & ND & $0.011 \pm 0.00(2)$ & $0.00 \%$ \\
Control & 1 & 11 & ND & ND & \\
& 2 & 5 & ND & ND & \\
& 3 & 8 & ND & ND & \\
\hline
\end{tabular}

$\mathrm{ND}=$ Not Detected $(p<0.005 \mu \mathrm{g} / \mathrm{g}$ wet weight $)$ 
TABLE 2. Egg shape (Mean \pm S.E.) of eggs of Tyto alba

\begin{tabular}{cccc}
\hline \multirow{2}{*}{ Treatment } & Bromadiolone & Egg shape (length to breadth $(\mathrm{L}: \mathrm{B}))$ & \\
& $1.228 \pm 0.01(n=7)$ & Chlorophacinone & Rodenticides free \\
\hline Season 1 & $1.229 \pm 0.04(n=11)$ & $1.224 \pm 0.04(n=4)$ & $1.229 \pm 0.01(n=11)$ \\
Season 2 & $1.232 \pm 0.02(n=8)$ & $1.232 \pm 0.02(n=15)$ & $1.224 \pm 0.01(n=5)$ \\
Season 3 & $1.230 \pm 0.02(n=11)$ & $1.227 \pm 0.03(n=19)$ & $1.227 \pm 0.04(n=4)$ \\
Season 4 & $1.230 \pm 0.03(n=37)^{\mathrm{ns}}$ & $1.232 \pm 0.03(n=18)$ & $1.230 \pm 0.01(n=4)$ \\
Mean & $1.229 \pm 0.03(n=56)^{\mathrm{ns}}$ & $1.228 \pm 0.02(n=24)^{\mathrm{ns}}$ \\
\hline
\end{tabular}

ns $=$ not significant $(p>0.05)$ according to Kruskal-Wallis test

four breeding seasons. The highest and the lowest ratios were $1.232 \pm 0.02(n=8)$ and $1.228 \pm 0.01(n=7)$ detected in the third breeding season and in the first breeding season, respectively. The total mean ratio from four breeding seasons combined in chlorophacinone treated plots was $1.229 \pm 0.03(n=56)$ slightly lower than bromadiolone treated plot and rodenticide free plot. There was no significant difference $(p>0.05)$ among the treatments. Naim et al. (2012) reported that the mean egg shape ratio of T. alba under baiting with brodifacoum and warfarin are 1.268 and 1.272, respectively. They also discovered a significant correlation between concentrations of brodifacoum and warfarin residues with egg shape i.e. more rounded with higher concentration of residues. However such association is not shown in this study with bromadiolone and chlorophacinone.

Table 3 shows eggshell mass of addled eggs from bromadiolone, chlorophacinone and rodenticide free plots. All measurements were consistent among the treatments throughout the four breeding seasons. In bromadiolone and chlorophacinone treated plots the average eggshell mass was $2268 \pm 23 \mathrm{mg}(n=37)$ and $2266 \pm 41 \mathrm{mg}(n=56)$, respectively. The measurements were not significantly different with rodenticide free area of $2268 \pm 16 \mathrm{mg}(n=24)$. The result showed that eggshell mass was not affected by application of bromadiolone and chlorophacinone. There are reports that brodifacoum and warfarin residues detected in addled egg lead to decrease in eggshell mass particularly when concentration of residues were at least $0.199 \mu \mathrm{g} / \mathrm{g}$ (Naim et al. 2012). The highest residue of bromadiolone and chlorophacinone detected in thi study was lower i.e. 0.052 and $0.020 \mu \mathrm{g} / \mathrm{g}$, respectively, which may not affect the eggshell mass.
Eggshell thicknesses in all treatment plots are consistent throughout the four breeding seasons (Table 4). In bromadiolone treated plot, the highest and corresponding lowest measurements of eggshell thickness were $0.278 \pm 0.01 \mathrm{~mm}(n=11)$ and $0.273 \pm 0.01 \mathrm{~mm}(n=17)$ with a total mean thickness of $0.275 \pm 0.01 \quad(n=37)$. In chlorophacinone treated plot, the highest and the lowest eggshell thickness was $0.279 \pm 0.01 \mathrm{~mm}(n=19)$ and $0.273 \pm 0.01 \mathrm{~mm}(n=15)$ recorded in the third and the second breeding season, respectively. The total mean eggshell thickness in chlorophacinone treated plot was $0.275 \pm 0.01(n=56)$. In rodenticide free area, the highest and corresponding lowest eggshell thicknesses were $0.278 \pm 0.01 \mathrm{~mm}(n=4)$ and $0.275 \pm 0.01 \mathrm{~mm}(n=4)$ found in the third and the fourth breeding season, respectively. The total mean eggshell thickness in rodenticide free area was $0.276 \pm 0.01(n=24)$. There was no significant difference $(p>0.05)$ of eggshell thickness within and among treatments in all breeding seasons of T. alba. The results indicated that bromadiolone and chlorophacinone do not affect eggshell thickness unlike other pesticides (Jaspers et al. 2005; Mendenhall et al. 1983) or environmental pollutants such as mercury (Castilla et al. 2009) and rodenticides such as brodifacoum and walfarin (Naim et al. 2012).

Naim et al. (2012) stated that mean eggshell thickness of T. alba under rat baiting with warfarin and brodifacoum ranging from $0.276-0.286 \mathrm{~mm}(n=18)$ and $0.260-0.291$ $\mathrm{mm}(n=18)$, respectively, while the mean eggshell thickness in rodenticide free area and biorodenticides ranges from $0.285-0.293 \mathrm{~mm}(n=9)$ and $0.283-0.286(n=14)$. They also reported that there are no significant difference $(p>0.05)$ between rodenticide treated area and non-rodenticide

TABLE 3. Eggshell mass (Mean \pm S.E) of eggs of Tyto alba

\begin{tabular}{cccc}
\hline \multirow{2}{*}{ Treatment } & Bromadiolone & $\begin{array}{c}\text { Eggshell mass }(\mathrm{mg}) \\
\text { Chlorophacinone }\end{array}$ & Rodenticides Free \\
\hline Season 1 & $2268 \pm 16(n=7)$ & $2265 \pm 34(n=4)$ & $2269 \pm 27(n=11)$ \\
Season 2 & $2270 \pm 29(n=11)$ & $2267 \pm 72(n=15)$ & $2268 \pm 16(n=5)$ \\
Season 3 & $2269 \pm 12(n=8)$ & $2265 \pm 24(n=19)$ & $2267 \pm 23(n=4)$ \\
Season 4 & $2266 \pm 28(n=11)$ & $2268 \pm 31(n=18)$ & $2268 \pm 17(n=4)$ \\
Mean & $2268 \pm 23(n=37)^{\mathrm{ns}}$ & $2266 \pm 41(n=56)^{\mathrm{ns}}$ & $2268 \pm 16(n=24)^{\mathrm{ns}}$ \\
\hline
\end{tabular}

$\mathrm{ns}=$ not significant $(p>0.05)$ according to Kruskal-Wallis test 
TABLE 4. Eggshell Thickness (Mean \pm S.E.) of eggs of Tyto alba

\begin{tabular}{cccc}
\hline Treatment & Bromadiolone & $\begin{array}{c}\text { Eggshell thickness }(\mathrm{mm}) \\
\text { Chlorophacinone }\end{array}$ & Rodenticides Free \\
\hline Season 1 & $0.273 \pm 0.01(n=7)$ & $0.275 \pm 0.01(n=4)$ & $0.277 \pm 0.00(n=11)$ \\
Season 2 & $0.278 \pm 0.01(n=11)$ & $0.273 \pm 0.01(n=15)$ & $0.276 \pm 0.00(n=5)$ \\
Season 3 & $0.275 \pm 0.00(n=8)$ & $0.279 \pm 0.01(n=19)$ & $0.278 \pm 0.01(n=4)$ \\
Season 4 & $0.273 \pm 0.01(n=11)$ & $0.275 \pm 0.01(n=18)$ & $0.275 \pm 0.01(n=4)$ \\
Mean & $0.275 \pm 0.01(n=37)$ & $0.275 \pm 0.01(n=56)$ & $0.276 \pm 0.01(n=24)^{\mathrm{ns}}$ \\
\hline
\end{tabular}

ns $=$ not significant $(p>0.05)$ according to Kruskal-Wallis test

areas. In USA, according to Klass et al. (1978) the mean eggshell thickness of T. alba $(n=129)$ before 1970's of pre DDT era in New Jersey, New York and Pennsylvania was $0.292 \mathrm{~mm}$. The mean eggshell thickness $(n=87)$ when DDT is heavily used is $0.276 \mathrm{~mm}$ which is almost $5.5 \%$ thinner than the archival eggshells. The mean eggshell thickness in this study was slightly lower compared to that reported by Klass et al. (1978) and Naim et al. (2012).

Several factors could influence the thinning of avian eggshells including season of the year, fertility status of parent, nutrition (in particular insufficient calcium, phosphorus, vitamin D and manganese) and breeding conditions (Dzoma et al. 2010; Koelkebeck 2012). Another factor such as the age of the parents plays a role in determining the functional quality of the egg shell. Older birds produce thinner eggshells while larger females tend to produce thicker eggshell (Koelkebeck 2012). They also reported human and predator intrusion is associated with thinner egg shells. Stress from noise, fear or excitement and disease are also associated with egg shell thinning (Dzoma 2010). Increase in temperature is also associated with thinner egg shells (Koelkebeck 2012). All these factors could contribute to the eggshells thinning of T. alba in the present study.

Many other substances could have been responsible for the thinning of eggshells. Environment pollutants such as organochlorines pesticides, polychlorinated biphenyls (PCB's) and heavy metal such as mercury could lower shell gland secretion and rate of calcium deposition leading to thinner avian eggshell (Tucker 1971). Lead and Mercury have been associated with egg shell thinning (Klaas et al. 1978; Tucker 1971). Phosphorus and calcium deficiency is associated with thinner shells (Crowley 1963; Taylor 1970). Lundholm (1997) reported that metabolic by-product of DDT (p,p'-DDE) inhibits prostaglandin synthetase, resulting in reduced calcium uptake by the shell gland mucosa during eggshell formation and results in thinning and will make breeding females crush their eggs during incubation.

Mendenhall et al. (1983) discovered DDE can lead to eggshell thinning, egg breakage, embryo mortality and reduced fecundity in T. alba. Jaspers et al. (2005) indicated concentrations of brominated diphenylethers (PBDEs), organochlorinated pesticides (OCPs) and PCBs could significantly lead to eggshell thinning in eggs of little owls (Athene noctua). In USA, Springer (1980) claims that the addlled eggs of great horned owl (Bubo virginianus) contain consistenanly higher pesticide levels and are on average 5\% thinner. In Australia, Olsen et al. (1993) stated that eggshell thickness of southern boobook owl decreases by $6.3 \%$ after introduction of DDT in the fields.

\section{CONCLUSION}

The detection of bromadiolone and chlorophacinone residue in albumen and yolk of eggs showed secondary poisoning in T. alba from both compounds. Bromadiolone and chlorophacinone residues from secondary poisoning can be transferred to the eggs of T. alba. However, the low residue presents in the albumen and yolk of eggs did not affect egg shape, egg shell mass or thinning of the eggshell.

\section{ACKNOWLEDGEMENTS}

We thank the following agencies for the successful completion of the study: The Office of the Deputy Vice Chancellor, Universiti Putra Malaysia (Research \& Innovation) for funding the research (vote no: 9199728) under Research University Grand Scheme (RUGS 5); The Felda Agricultural Services Sdn Bhd (FASSB), Malaysia for providing the study sites in the oil palm plantation at the Tun Razak Agriculture Research Centre (PPPTR), Felda Jengka 24 and Felda Kota Gelanggi 05, Pahang, Malaysia.

\section{REFERENCES}

Castilla, A.M., Herrel, A., Van Dongen, S., Furio, N. \& Negro, J. 2009. Determinants of eggshell strength in endangered raptors. Journal of Experimental Zoology 311A: 303-311.

Crowley, T.A. 1963. Calcium deficiency is associated with thinner shells. Poultry Science 54: 350-368.

Dzoma, B.M. 2010. Some factors affecting fertility and hatchability in farmed ostrich: A review. Journal of Animal and Veterinary Advances 9(2): 229-239.

Eeva, T., Lehikoinen, E. \& Pohjalainen,T. 1997. Pollution-related variation in food supply and breeding success in two holenestling passerines. Ecology 78: 1120-1131.

Erickson, W. \& Urban, D. 2004. Potential Risks of Nine Rodenticides to Birds and Nontarget Mammals: A comparative approach. Washington, DC, USA, United States Enviromental Protection Agency, Office of Pesticides Programs Environmental Fate and Effects Division. p. 225.

Fisher, P.M. 2009. Residual concentration and persistence of the anticoagulant rodenticides Brodifacoum and Diphacinone 
in fauna. Ph.D. Thesis. Lincoln University, New Zealand. p. 155 (unpublished).

Green, R.E. 1998. Long-term decline in the thickness of eggshells of thrushes, Turdus spp., in Britain. Proceedings of Royal Society, Biological Sciences 265: 679-684.

Jaspers, V., Covaci, A., Maervoet, J., Dauwe, T., Voorspoels, S., Schepens, P. \& Eens, M. 2005. Brominated flame retardants and organochlorine pollutants in eggs of little owls (Athene noctua) from Belgium. Environmental Pollution 136: 81-88.

Kammerer, M., Pouliquen, H., Pinault, L. \& Loyau, M. 1999. Residues depletion in egg after warfarin ingestion by laying hens. Veterinary and Human Toxicology 40(5): 273-275.

Klass, E.E., Wiemeyer, S.N., Ohlendorf, H.M. \& Swineford, D.M. 1978. Organochlorine residues, eggshell thickness and nest success in barn wols from the Chesapeake Bay. Estuaries 1: 46-53.

Koelkebeck, K.W. 2012. What is eggshell quality and how to preserve it? Cheva-Eggs Program 8(4): 1-2.

Lundholm, C.E. 1997. DDE-Induced eggshell thinning in birds: Effects of p,p'-DDE on the calcium and prostaglandin metabolism of the eggshell gland. Comparative Biology and Physiology 118C(2): 113-128.

Mario, G. \& Grazia, M. 2010. An HPLC method for the determination of bromadiolone plasma kinetics and its residues in hen eggs. Journal of Chromatographic Science 48(9): 714-720.

Mendenhall, V.M., Klass, E.E. \& McLane, M.A.R. 1983. Breeding success of of Barn Owls (Tyto alba) fed low levels of DDE and Dieldrin. Archieves in Environmental Contamination and Toxicology 12: 235-240.

Naim, M., Hafidzi, M.N., Sudharto, P.S. \& Caliman, J.P. 2012. Detection of rodenticide residues for raptor conservation. 3rd International Conference on Oil Palm and Environment (ICOPE), Bali, Indonesia. 22-24 February.

Olsen, P., Fuller, P. \& Marples, T.G. 1993. Pesticide-related eggshell thinning in Australian raptors. Emu. 93: 1-11.

Pouliquen, H., Fauconnet, V., Morvan, M.L. \& Pinault, L. 1997. Determination of Warfarin in the yolk and the white of hens eggs by reverse-phase high-performance liquid chromatography. Journal of Chromatography 702: 143-148.
Robertson, H.A., Colbourne, R.M., Graham, P.J., Miller, P.J. \& Pierce, R.J. 1999. Survival of brown kiwi (Apteryx mantelli) exposed to brodifacoum poison in Northland, New Zealand. New Zealand Journal of Ecology 23: 225-231.

Springer, A.S. 1980. Pesticide levels, egg and eggshell parameter of great Horned Owls. Ohio Journal of Science 80: 184-187

Taylor, T.G. 1970. How an eggshell is made. Scientific American 222: 88-95.

Tucker, R.K. 1971. Effects of many chemicals on shell thickness. Utah Science 6: 47-49.

Hasber Salim, Hafidzi Mohd Noor* \& Dzolkhifli Omar Department of Plant Protection, Faculty of Agriculture Universiti Putra Malaysia 43400 Serdang, Selangor Darul Ehsan Malaysia

Noor Hisham Hamid \& Cik Mohd Rizuan Z. Abidin Crop Protection Division

Felda Agricultural Services Sdn Bhd Tun Razak Agriculture Research Centre 27000 Pahang Darul Makmur Malaysia

\section{Azhar Kasim}

Department of Animal Science, Faculty of Agriculture Universiti Putra Malaysia

43400 Serdang, Selangor Darul Ehsan

Malaysia

*Corresponding author; email: hafidzi@upm.edu.my

Received: 26 July 2013

Accepted: 30 October 2014 